\title{
Effect of Fermentation (Natural and Starter) on the Physicochemical, Anti-nutritional and Proximate Composition of Pearl Millet Used for Flour Production
}

\author{
Onuoha Elizabeth Chinenye, Orukotan Abimbola Ayodeji, Ameh Joseph Baba \\ Department of Microbiology, Faculty of Science, Kaduna State University, Kaduna, Nigeria \\ Email address: \\ onuoha.elizabeth@yahoo.com (O. E. Chinenye) \\ To cite this article: \\ Onuoha Elizabeth Chinenye, Orukotan Abimbola Ayodeji, Ameh Joseph Baba. Effect of Fermentation (Natural and Starter) on the \\ Physicochemical, Anti-nutritional and Proximate Composition of Pearl Millet Used for Flour Production. American Journal of Bioscience \\ and Bioengineering. Vol. 5, No. 1, 2017, pp. 12-16. doi: 10.11648/j.bio.20170501.13
}

Received: October 31, 2016; Accepted: January 16, 2017; Published: February 10, 2017

\begin{abstract}
Fermentation of foods has been practiced for improving the flavor, texture and palatability of foods. Fermentation also leads to an increase in protein content, enhancement of carbohydrate accessibility, decrease of antinutritional factors like tannin and phytic acid. This study was carried out to determine the effect of fermentation on the physicochemical, antinutrients and nutritional composition with the aim of producing flour from Pearl millet (Sosart 1). Sterile millet grains were inoculated with Lactobacillus plantarum using a $0.5 \mathrm{McFarland}$ standard while a different batch of millet grains were steeped in water without an inoculum; they were allowed to ferment for 4 days. The $\mathrm{pH}$ values of the fermenting samples were analyzed daily. Results obtained showed that the $\mathrm{pH}$ values for starter and natural fermentation were between 3.64-3.48 and 4.94-4.55 respectively. These were accompanied with a gradual increase in total titratable acidity with values of 0.090- 0.819 and $0.317-$ 0.756 for both starter and natural fermentation respectively. Evaluation of grain anti-nutritional composition showed that the phytate and tannin were significantly decreased by fermentation. The nutritional compositions of the grains were also improved by fermentation resulting in protein and moisture content increase. Fermentation has proved to have a potential to improve protein and decrease antinutrient contents of pearl millet for production of flour. This can be incorporated in the formulation of weaning foods and production of confectioneries for both children and adults.
\end{abstract}

Keywords: Fermentation, Pearl Millet, Lactobacillus plantarum, Proximate, Physicochemical

\section{Introduction}

Cereal grains are the most important source of the world's food and have a significant role in human diet throughout the world. Pearl millet (Pennisetum glaucum) is one of the important crops in semi-arid areas of Africa and India [1]. Pearl millet crop has a wide adaptability to local environment for its properties of been tolerant to drought and heat. For this reason, it is widely grown in tropical regions of the world including Africa and Asia [1]. Pearl millet is currently the world's sixth most important cereal grain and is grown extensively in Africa, Asia, India and the Near East as a food grain and is the staple source of the nutrition for millions of people [1]. It serves as a major food component in various traditional foods and beverages such as bread, porridges and snack foods, specifically among the non-affluent segments in their respective societies [2].

Fermentation of foods has been practiced for improving the flavor, texture and palatability of foods. Pearl millet has a high nutrient content but bioavailability is low, inherently due to the presence of antinutritional factors, such as phytic acid, polyphenols and tannins. Fermentation is one of the processes known to reduce these anti-nutrients [1]. Fermentation also leads to an increase in protein content [3], enhancement of carbohydrate accessibility [4], improvement in amino acid balance, decrease in antinutritional factors like tannin and phytic acid [5]. Household fermentation technologies have been upgraded to an industrial scale in order to provide value added products that meet urban population demand for traditional products [6].

In lactic acid fermented foods, the acidity is usually below $\mathrm{pH}$ 4.5. Most pathogenic microorganisms found in food cannot 
survive at this low $\mathrm{pH}$, hence, lactic acid fermentation has been found to reduce the risk of growth of pathogenic microorganisms in the food [1]. Probiotic are beneficial bacteria that favorably alter the intestinal microflora balance, inhibit the growth of harmful bacteria, promote good digestion, boost immune function and increase resistance to infection [1]. The objectives of this study was to determine the effect of fermentation (natural and starter) on physicochemical properties, anti-nutrient and proximate composition of pearl millet (Sosart 1) used for flour production.

\section{Materials and Methods}

\subsection{Collection of Samples}

Hybrid variety of pearl millet (Sosart 1) was purchased from the Institute of Agricultural Research (IAR) Samaru at Ahmadu Bello University, Zaria. Samples wereaseptically collected in clean polyethylene bags and taken to the laboratory for further analysis. Pure cultures of Lactobacillus plantarum was obtained from microbial culture bank of the Department of Microbiology, Kaduna State University, Kaduna.

\subsection{Processing of Millet Flour}

\subsubsection{Natural Fermentation of Millet Grains}

Two and half $\left(2^{1 / 2}\right)$ kilograms $(\mathrm{kg})$ of grains were sorted out by removing the debris, stones e.t.c, cleaned and shared into two portions. 1250 grams (g) were washed thoroughly after which these were steeped in a sterile container containing sterile distilled water and allowed to ferment at $37^{\circ} \mathrm{C}$ for four (4) days. The grains were separated from the steep water, dried at $55^{\circ} \mathrm{C}$ and hammer milled into fine flour (70 mesh screen). The flours were stored in screw capped jars until used for further analysis as described by [7].

\subsubsection{Fermentation of Millet Using Pure Cultures of Lactobacillus Plantarum}

The grains were packed in air tight bottles and autoclave at $121^{\circ} \mathrm{C}$ for 15 minutes. The sterile grains were allowed to cool to room temperature before inoculation [8]. Pure cultures of the Lactobacillus plantarum plated on De Man Rogosa Sharpe agar at $30^{\circ} \mathrm{C}$ for 24 hours were used to prepare a ten (10) fold serial dilutions. Using a $0.5 \mathrm{McF}$ arland standard the starter culture was inoculated into the sterile sample and allowed to ferment at $37^{\circ} \mathrm{C}$ for 4 days (96 hours). At the end of fermentation period the grains were separated from the steep water and dried at $55^{\circ} \mathrm{C}$ and hammer milled into fine flour (70 mesh screen). The flours were kept in screw capped jars until used for further analysis [8].

\subsection{Physico-Chemical Analysis of Millet During Fermentation}

\subsubsection{PH Determination}

The samples were thoroughly stirred to homogenize the mixture and achieve uniformity. The $\mathrm{pH}$ electrode was dipped into the sample and measurement was taken using a HANNAH pH Meter 209 as described by [9].

\subsubsection{Total Titer Acidity}

Aliquot $(10 \mathrm{ml})$ of the fermenting sample of millet was pipette into an Erlenmeyer flask, and then 2drops of phenolphthalein was added. This was titrated using $0.1 \mathrm{~N}$ $\mathrm{NaOH}$ until a faint pink color appeared. The titer volume was noted and used to calculate Total Titer Acidity (TTA) which was expressed as Percentage Lactic Acid [10]. TTA was determined and expressed as follows:

$\%$ Lactic acid $=\mathrm{A} \times 0.009 \times 100 / \mathrm{V}$;

Where $\mathrm{A}=\mathrm{ml}$ of $0.1 \mathrm{NaOH}$ required for the titration; and $\mathrm{V}=\mathrm{ml}$ of sample taken for the test.

The acidity was calculated as lactic acid using the relationship:

$$
\frac{\text { Volume of base used } x \text { Normality of } \mathrm{NaOH}(N) \times 9}{\text { Volume of Sample used (average titer) }}
$$

\subsection{Proximate Composition}

The percentage of protein, ash, crude fiber and fat content of the samples were analyzed using the standard methods of [11]. Carbohydrate (\%) was determined as follows: \% carbohydrate $=100 \%-(\%$ crude protein $+\%$ fat $+\%$ ash $+\%$ Crude fibre $+\%$ moisture $)$

\subsection{Anti-nutrients Determination}

Phytate content was determined using the method of [12]. The tannin content was determined by the vanillin- $\mathrm{HCl}$ method as described by [11].

\section{Results and Discussion}

It was observed that the $\mathrm{pH}$ values of the fermented samples were acidic at the 0hour (5.00 and 5.75) for starter and natural fermented millet grains, but became more acidic as fermentation progressed from 0hour to 96 hours (Table 1). The $\mathrm{pH}$ value of the starter fermented sample decreased as the fermentation progressed from 0hour to 96 hours. This decrease in $\mathrm{pH}$ could be attributed to the production of organic acids in the fermenting grains as reported by [13]. There was no significant difference in the $\mathrm{pH}$ at 24 hours to 96 hours indicating that fermentation can be achieved at a short period of time using starter culture. Fermentation was observed to occur immediately after 24 hours of incubation (Table 1). A similar result within a short period of fermentation was observed by [13], who revealed that $\mathrm{pH}$ less than 4.0 was reached within 12-24 hours using microorganisms singly or in mixed cultures. Such a short fermentation period is desirable to obtain a product of good and consistent quality. Lactic bacteria (LAB) are commonly involved in the fermentation of carbohydrate based substrates [1]. Both fermented samples were observed to decrease in $\mathrm{pH}$; this could be attributed to the accelerated growth rate of lactic acid bacteria (Table 1). This is in agreement with [14] who reported a decrease in $\mathrm{pH}$ as the fermentation progressed. The observed increase in titratable acidity could be due to the dominance of the environment by lactic acid 
bacteria which degrades carbohydrates resulting in acidification. These observations are in agreement with earlier studies by [15].

Millet has been observed to contain some antinutritional content such as tannin and phytate, which were 2.80 and 1.78 respectively (Table 2). Significant reduction $(\mathrm{P}<0.05)$ in phytate and tannin were observed for both fermented grains, with the highest reduction in the starter fermented millet sample (0.09 and 0.08) as compared to the natural fermented sample $(0.12$ and 1.85$)$ respectively (Table 2$)$. This is in conformity with the findings of [16] who reported a significant reductions $(\mathrm{P}<0.05)$ in the antinutrients contents of Ogwo (fermented sorghum- Irish potato gruel) where the highest reduction of antinutrients were found in samples fermented with starter cultures compare to the samples fermented naturally. He reported highest reductions in the phytic acid, saponins, flavonoids contents of Lactobacillus plantarum fermented sample, and in oxalate and tannin contents of sample fermented with Saccharomyces cerevesiae and Lactobacillus acidophilus respectively.

The reduction in the anti-nutrient contents after fermentation could be due to leaching of the anti-nutrients into the soaking (Table 2). This is in agreement with [17] which study the effect of fermentation on some chemical and physical properties of maize. Reduction in tannin contents reduces the risk of bowel irritation, kidney irritation, liver damage, irritation of the stomach and gastrointestinal pain which are associated with foods containing high level of tannin. The fermenting microorganisms are responsible for the cleavages of tannin-protein, tannic acid-starch and tanniniron complexes thereby releasing the free nutrients which will invariably improve the availability of the nutrients [7]. The decrease in phytate levels in all fermented samples could be due to the activities of such microorganisms during fermentation.

An increase in protein content was observed after 96 hours of fermentation of millet grains using starter and natural fermentation (Table 3). This agrees with the findings of [18] who reported a significant increase in the protein content of pearl millet. This is also in conformity with findings made by [9 and 19]. Increase in protein content could be attributed to the loss of dry matter, mainly carbohydrates or due to the action of extracellular enzymes produced by the fermenting microorganisms [15]. [21 and 22] reported a marginal change in protein content of fermented sorghum, while [23] observed a decrease in protein in fermented sorghum. An increase in protein content was observed after fermentation; this could be due to the activities and increase in number of lactic acid bacteria present during fermentation. The increase in protein contents agrees with the findings of [24] who reported that the use of fermentation may prove as a means of improving product functionality and protein contents.

There was a decrease in the Lipid content of the fermented pearl millet from 10.34 to 0.34 and 0.74 for both starter and natural fermented grains respectively (Table 3 ). This is in conformity with the findings of [9] who reported a significant decrease $(\mathrm{P}<0.05)$ in the lipid content of fermented millet flour after 72 hours of fermentation from 5.7 to 2.4. The low lipid content observed in the fermented sample could help in increasing of the sample shelf life by decreasing the chances of rancidity, and will also contribute to the low energy value of the samples (Table 3). A contradictory report was made by [25] who reported an increase in the lipid content of pearl millet fermented for periods of 24, 48 and 72 hours.

An increase in the moisture content of fermented millet (natural and starter) grains agrees with the findings of [26] who reported that fermentation of pearl millet caused an appreciable change in the nutritional composition. Furthermore it was found that during 24 hours fermentation of pearl millet there was a significant difference $(\mathrm{P}<0.05)$ in protein, and lipid contents. Carbohydrate content significantly $(\mathrm{P}<0.05)$ decreased with a parallel increase in soluble sugars, that agrees with the data reported by [5].

Table 1. $p H$ and Total Titratable values of Millet Grains at Different Fermentation Time.

\begin{tabular}{lllll}
\hline $\begin{array}{l}\text { Fermentation } \\
\text { time }\end{array}$ & $\begin{array}{l}{ }_{\mathbf{P}} \mathbf{H} \\
(\text { Starter) }\end{array}$ & $\begin{array}{l}\text { TTA } \\
(\text { Starter) }\end{array}$ & $\begin{array}{l}{ }_{\mathbf{P}} \mathbf{H} \\
\text { (Natural) }^{\mathrm{b}}\end{array}$ & $\begin{array}{l}\text { TTA } \\
\text { (Natural) }\end{array}$ \\
\hline 0 hours & $5.00 \pm 0.80^{\mathrm{b}}$ & $0.090 \pm 0.002^{\mathrm{a}}$ & $5.02 \pm 0.68^{\mathrm{a}}$ & $0.137 \pm 0.006^{\mathrm{a}}$ \\
24 hours & $3.64 \pm 0.42^{\mathrm{a}}$ & $0.423 \pm 0.004^{\mathrm{b}}$ & $4.94 \pm 0.56^{\mathrm{a}}$ & $0.243 \pm 0.003^{\mathrm{b}}$ \\
48 hours & $3.57 \pm 0.36^{\mathrm{a}}$ & $0.441 \pm 0.005^{\mathrm{b}}$ & $4.80 \pm 0.48^{\mathrm{a}}$ & $0.342 \pm 0.004^{\mathrm{c}}$ \\
72 hours & $3.52 \pm 0.25^{\mathrm{a}}$ & $0.801 \pm 0.024^{\mathrm{c}}$ & $4.78 \pm 0.79^{\mathrm{a}}$ & $0.693 \pm 0.020^{\mathrm{d}}$ \\
96 hours & $3.48 \pm 0.32^{\mathrm{a}}$ & $0.819 \pm 0.040^{\mathrm{c}}$ & $4.55 \pm 0.64^{\mathrm{a}}$ & $0.756 \pm 0.030^{\mathrm{e}}$ \\
\hline
\end{tabular}

Values are Mean $\pm \mathrm{SD}$; Values with different superscript within the column are significantly different $(\mathrm{P}<0.05)$ by Duncan multiple range test

Table 2. Antinutritional Composition of Fermented and Unfermented Grains.

\begin{tabular}{lll}
\hline Sample Name & Phytate & Tannin \\
\hline UFM & $1.78 \pm 0.24^{\mathrm{b}}$ & $2.80 \pm 0.30^{\mathrm{b}}$ \\
SFM & $0.09 \pm 0.03^{\mathrm{a}}$ & $1.40 \pm 0.08^{\mathrm{a}}$ \\
NFM & $0.12 \pm 0.04^{\mathrm{a}}$ & $1.85 \pm 0.06^{\mathrm{a}}$ \\
\hline
\end{tabular}

Values are Mean $\pm \mathrm{SD}$; Values with different superscript within the column are significantly different $(\mathrm{P}<0.05)$ by Duncan multiple range test

Key: UFM=Unfermented Millet, $\mathrm{SFM}=$ Starter Fermented Millet, NFM=Natural Fermented Millet.

Table 3. Proximate Composition of Fermented and Unfermented Grains.

\begin{tabular}{lllllll}
\hline Sample Name & \%Moisture & \% Ash & \%Lipid & \%Protein & \%CHO \\
\hline UFM & $5.74 \pm 0.82^{\mathrm{a}}$ & $8.73 \pm 1.02^{\mathrm{b}}$ & $10.39 \pm 1.40^{\mathrm{b}}$ & $8.73 \pm 1.07^{\mathrm{a}}$ & $72.78 \pm 1.48^{\mathrm{b}}$ \\
SFM & $7.58 \pm 0.68^{\mathrm{b}}$ & $0.34 \pm 0.04^{\mathrm{a}}$ & $0.64 \pm 0.01^{\mathrm{a}}$ & $20.54 \pm 1.08^{\mathrm{b}}$ & $719.55 \pm 2.26^{\mathrm{c}}$ & $70.90 \pm 1.28^{\mathrm{ab}}$ \\
NFM & $6.37 \pm 0.57^{\mathrm{ab}}$ & $0.74 \pm 0.03^{\mathrm{a}}$ & $0.74 \pm 0.06^{\mathrm{a}}$ & $20.21 \pm 1.60^{\mathrm{b}}$ & $69.91 \pm 1.39^{\mathrm{a}}$ & $371.52 \pm 1.96^{\mathrm{a}}$ \\
\hline
\end{tabular}

Values are Mean $\pm \mathrm{SD}$; Values with different superscript within the column are significantly different $(\mathrm{P}<0.05)$ by Duncan multiple range test Key: UFM=Unfermented Millet, SFM= Starter Fermented Millet, NFM=Natural Fermented Millet, 


\section{Conclusion}

In conclusion, fermented millet grains using starter or natural fermentation has high and promising nutrient potentials, and as such, should be incorporated in many food preparations especially complementary foods and snacks that are widely consumed by children and adolescents. Production, processing and utilization of this under exploited cereal should be promoted as they could be valuable in the persistent fight against hunger and malnutrition. Fermentation of this grain has shown improvement of the value of nutrients that is accessible to the body, and reduction of the antinutrients.

\section{Acknowledgement}

These authors wish to acknowledge the staff of industrial microbiology laboratory of Kaduna state University.

\section{References}

[1] Ranasalva, N. and Visvanathan R. (2014). Development of cookies and bread from cooked and fermented pearl millet flour. African Journal of Food Science. 8 (6): 330-336.

[2] Chandrasekara, A. and. Shahidi, F (2010). Content of insoluble bound phenolics in millets and their contribution to antioxidant capacity. Journal of Agriculture and Food Chemistry. 58: 6706-6714.

[3] Nor, A. M., Wan, Z., Wan, I. and Amar, S. (2015). Effects of protein content in selected fish towards the production of lactic acid bacteria (Lactobacillus spp) during production of Pekasam. Current Research in Nutrition and Food Science, 3 (3).

[4] Elkhalifa, E. O., Schiffler, B. and Bernhard, R. (2004). Effect of fermentation on the starch digestibility, resistant starch and some physicochemical properties of sorghum Flour. African Journals online, 48: 91 - 94.

[5] Osman, M. A. (2004). Change in sorghum enzyme inhibitors phytic acid, tannins and in vitro protein digestibility occurring during Khamir (local bread) fermentation. Journal of the Saudi Society of Agricultural Sciences, 88: 129-134.

[6] Correia, A., Nunes, S. and Guedes, A. S. (2010) Screening of lactic acid bacteria potentially useful for sorghum fermentation. Journal of Cereal Science, 52: 9-15.

[7] Onweluzo, J. C. and Nwabugwu, C. C. (2009). Fermentation of millet (Pennisetumamericanum) and pigeon pea (Cajanuscajan) seeds for flour production: Effects on composition and selected functional properties. Pakistan Journal of Nutrition, 8 (6): 737-744.

[8] Omemu A. M., Oyewole O. B., Bankole,M. O and Akintokun, A. K. (2007) yeast and moulds associated with Ogi-a cereal base waning food during storage. Research Journal of Microbiology.2 (2) 141-148.

[9] Anthony. O and Babatunde B. (2014) Effect of Fermentation on Nutrient and Antinutrients composition of millet (Pennisetum glaucum) and soya bean (Glycine max) blend of flours. Journal of Life Sciences Vol 8 (8) pp 668-675
[10] AOAC (2006). Official Methods of Analysis, 18th ed Association of Official Analytical Chemists, Washington, D. C.

[11] AOAC, (2005). Official Methods for Analysis, 16th ed. Association of Official Analytical chemists, Washington D.C.

[12] Nkama, I. and Gbenyi, D. I. (2001). The effect of malting of millet and sorghum on the residual phytate and polyphenols in Dakuwa-a Nigerian cereal-legumes snack food. Journal of Tropical Agriculture, pp: 270-275.

[13] Wakil, S. M and Kazeem, M. O. (2012). Quality assessment of weaning food produced from fermented cereal-legume blends using starters. International Food Research Journal 19 (4): 1679-1685.

[14] Inyang, C. D and Idoko, C. A.(2006). Assessment of the quality of Ogi made from malted millet. African Journal of Biotechnology (5): 2334-2337.

[15] Apena A., Opeolu S. O., Bamidele. F. A. and Shittu, A., 2015. Nutrient changes during fermentation of some selected cereals. Sky Journal of Biochemistry Research. 4 (2): 10-12.

[16] Adegbehingbe, K. T. (2015) Effect of starter cultures on the anti-nutrient contents, minerals and viscosity of Ogwo, a fermented sorghum-Irish potato gruel. International Food Research Journal 22 (3): 1247-1252.

[17] Gernah, O. I, Ariahu, C. C and Ingbian, E. K (2011). Effect of Malting and Lactic Fermentation on Some Chemical and Functional Properties of Maize (Zea mays). American Journal of Food Technology 6 (5): 404-412.

[18] Fasasi, O. S (2009). Proximate, Antinutritional Factors and Functional Properties of Processed Millet Flour. Journal of Food Technology 7 (3): 92-97.

[19] Elyas, S. H., El-Tinay, A. H., Yosif, N. E. and Elsheikh, E. A., (2002). Effect of fermentation on nutritive value and in vitro protein digestibility of pearl millet. Food Chemistry. 78, 75-79.

[20] Inyang, C. U. and Zakari, U. M. (2008). Effect of germination and fermentation of pearl millet on proximate, chemical and sensory properties of instant, Fura-Nigerian cereal food. Pakistan Journal of Nutrition 7: 9-12.

[21] Ali, A. M., El-Tinay, H. A. and Abdalla, H. A., (2003). Effect of fermentation on the in vitro digestibility of pear millet. Food Chem. 80, 51-54.

[22] Hassan, A. B., Mohamed Ahmed, I. A., Osman, N. M., Eltayeb, M. M., Osman, G. A. and Babiker, E. E. (2006). Effect of processing treatment followed by fermentation on protein content and digestibility of pearl millet (Pennisetum typhoideum) cultivars. Pakistan Journal of Nutrition 5 (1): 86-89.

[23] EL Hag, M. E., El Tinay, A. H. and Yousif, N. E., (2002). Effect of fermentation and dehulling on starch, total polyphenols, phytic acid and in vitro digestibility of pearl millet. Food Chemistry. 77, 193-196.

[24] Afoakwa, E. O., Sefa-Deheh, S., Kluvitse, Y and SakyiDawson, E. O (2004). "The Influence of Fermentation and Cowpea Fortification on the Quality Characteristics of Maizebased Weaning Foods." Presented at the Second International Workshop on Food-based Approaches for Healthy Nutrition in West Africa: The Role of Food Technologists and Nutritionists, Ouagadougou, Burkina Faso 
[25] Chikwendu J. N, Obiakor, O. P and Maduforo, A. N (2014). Effect of Fermentation on the nutrient and antinutrients composition of African yam bean (sphenosty lisstenocarpa) seeds and Pearl millet (Pennisetum glaucum) grain. International Journal of Science and Technology vol (2): 169173.
[26] Ahmed, B. M., Hamed, R. A., Ali, M. A., Hassan A. B. and Babiker, E. E. (2009). Proximate composition, antinutritional factors and protein fraction of Guar seeds as influenced by processing treatments. Pakistan Journal of Nutrition5: 481484. 